\title{
Control and Analysis of an Integrated Bidirectional DC/AC and DC/DC Converters for Plug-In Hybrid Electric Vehicle Applications
}

\author{
Omar Hegazy $^{\dagger}$, Joeri Van Mierlo*, and Philippe Lataire* \\ $\dagger *$ Dept. of Electrical Engineering and Energy Technology (ETEC), Vrije Universiteit Brussel (VUB), Brussels, Belgium
}

\begin{abstract}
The plug-in hybrid electric vehicles (PHEVs) are specialized hybrid electric vehicles that have the potential to obtain enough energy for average daily commuting from batteries. The PHEV battery would be recharged from the power grid at home or at work and would thus allow for a reduction in the overall fuel consumption. This paper proposes an integrated power electronics interface for PHEVs, which consists of a novel Eight-Switch Inverter (ESI) and an interleaved DC/DC converter, in order to reduce the cost, the mass and the size of the power electronics unit (PEU) with high performance at any operating mode. In the proposed configuration, a novel Eight-Switch Inverter (ESI) is able to function as a bidirectional single-phase AC/DC battery charger/ vehicle to grid (V2G) and to transfer electrical energy between the DC-link (connected to the battery) and the electric traction system as DC/AC inverter. In addition, a bidirectional-interleaved DC/DC converter with dual-loop controller is proposed for interfacing the ESI to a low-voltage battery pack in order to minimize the ripple of the battery current and to improve the efficiency of the DC system with lower inductor size. To validate the performance of the proposed configuration, the indirect field-oriented control (IFOC) based on particle swarm optimization (PSO) is proposed to optimize the efficiency of the AC drive system in PHEVs. The maximum efficiency of the motor is obtained by the evaluation of optimal rotor flux at any operating point, where the PSO is applied to evaluate the optimal flux. Moreover, an improved AC/DC controller based Proportional-Resonant Control (PRC) is proposed in order to reduce the THD of the input current in charger/V2G modes. The proposed configuration is analyzed and its performance is validated using simulated results obtained in MATLAB/ SIMULINK. Furthermore, it is experimentally validated with results obtained from the prototypes that have been developed and built in the laboratory based on TMS320F2808 DSP.
\end{abstract}

Key Words: Dual-loop control, Eight-Switch Inverter (ESI), IFOC, Interleaved DC/DC Converter, Loss Model of the induction motor, Particle Swarm Optimization (PSO), Plug-In Hybrid Electric Vehicle, Proportional- Resonant Controller (PRC)

\section{INTRODUCTION}

In recent years, there has been a lot of interest in the concept of plug-in hybrid electric vehicles, which have great potential to achieve higher fuel economy and efficiency, with a longer range in pure electric propulsion mode. The plugin hybrid electric vehicle (PHEV) is a hybrid electric vehicle with an energy storage system (ESS) that can be recharged by connecting the vehicle plug to an external electric power source (such as the electric utility grid) [1].

Furthermore, Hybrid Electric Vehicles (HEVs), especially PHEVs have become an interesting alternative to conventional vehicles due to their capability of reducing fuel consumption, Zero-exhaust emissions and sizes of batteries / Supercapacitors on board while maintaining long vehicle ranges. Plugin hybrids provide significantly improved performance and flexibility when compared with conventional vehicles.

\footnotetext{
Manuscript received Dec. 31, 2010; revised Mar. 17, 2011
}

Recommended for publication by Guest Associate Editor Byoung-Kuk Lee.

$\dagger$ Corresponding Author: Omar.hegazy@vub.ac.be

Tel: +32-2629-2992, Fax: +32-2629-3620, Vrije Universiteit Brussel

$*$ Dept. of ETEC, Vrije Universiteit Brussel (VUB), Belgium
Recently the PHEV motor drive, power electronic units and energy storage technology have developed at a rapid rate in response to expected market demand for PHEVs. Therefore, the power switching devices and associated control systems play a key role in bringing plug-in hybrid vehicles to market with reliability and affordability [1]-[4]. The power electronic system should be efficient to improve the range of the electric operation and fuel economy. The selection of power semiconductor devices, converters/inverters, control and switching strategies, the packaging of the individual units, and the system integration are very essential to the development of efficient and high performance PHEVs [2].

Battery chargers are another key component required for the emergence and acceptance of PHEVs. Generally, there are two types of battery chargers: off-board (standalone) and on-board (integrated charger). Several integrated chargers in vehicle applications have been reported by the academia or industry [5]-[9]. Especially, an on-board battery charger has to be small and light in order to maximize energy efficiency and the distance covered per charging. Therefore, several bidirectional ac-de converter topologies can be used as on- 
board battery charger. The specific topology chosen depends on the PHEV requirements, for example the efficiency, reliability, cost, volume and weight. There are two strategies for the bidirectional ac-dc converter design: one is that the bidirectional converter separates from the driving system. The other one is to combine the electric motor like filter and the same converter for charging mode and traction mode [1]-[9]. Furthermore, the bidirectional $\mathrm{dc} / \mathrm{dc}$ converter with a proper charging/discharging profile is required to transfer energy between the battery pack and the electric traction system in order to reduce the size and weight of the battery pack [5], [8].

The purpose of this paper is to present an integrated configuration and to demonstrate its feasibility for PHEVs conversion. In this paper, a new converter topology, eight-switch inverter (ESI), is proposed to implement the integration of the PHEV with the grid as a bidirectional single-phase AC/DC (On-Board Charger) and to achieve the traction mode as DC/AC inverter with high performance, low cost and low volume compared with other topologies. The different operating modes of the proposed converter are given and the evaluations are provided in Section II. In addition, a bidirectional DC/DC interleaved converter and its controller are presented for the battery pack to maintain the DC-link voltage with high efficiency compared with conventional DC/DC converter. In this research, four control strategies are investigated to validate the performance of the proposed topology. These are indirect field-oriented controller (IFOC), IFOC based on PSO, Dual-loop controller for the interleaved DC/DC converter control and PWM current control based Proportional-Resonant Controller (PRC) for the integrated charger control. The PRC is compared with other controllers. Informative simulation is carried out and experiment is performed using $30 \mathrm{~kW}$ lab-prototypes to verify the validity of the proposed topology.

\section{The Proposed Configuration}

Fig. 1 illustrates the proposed configuration of the PHEV during the charge depletion (CD) mode. In this mode, the net energy stored in batteries will decrease over a driving profile. The depletion process will be ended at about $20 \%$ of the battery state of charge (SoC).

\section{A. The Bidirectional DC/AC Converter}

The structure of the proposed DC/AC converter, ESI, is illustrated in Fig. 2. This converter consists of eight switches, which are connected in the sequence of $3 / 3 / 2$ as shown in Fig.2. With the proposed converter, there are four operating modes. In these modes, the converter has the ability to:

1) Operate as a DC/AC inverter, Mode1, which transfers the power from DC-link to the motor;

2) Operate as a three-phase PWM AC/DC rectifier, Mode2, which transfers the power from motor to DC-link;

3) Operate as a single-phase PWM AC/DC converter, Mode 3 , which charges the battery from the grid, and

4) Operate as a single-phase DC/AC inverter, Mode 4, which delivers power back from battery pack to the utility during peak load. This mode is called "Vehicle to Grid" (V2G) mode or "Vehicle to Home" V2H mode.

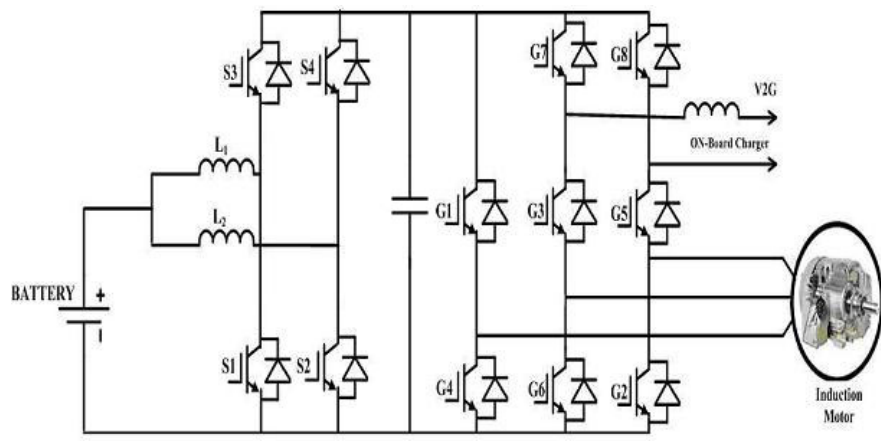

Fig. 1. The structure of the proposed configuration for PHEV during CD Mode.

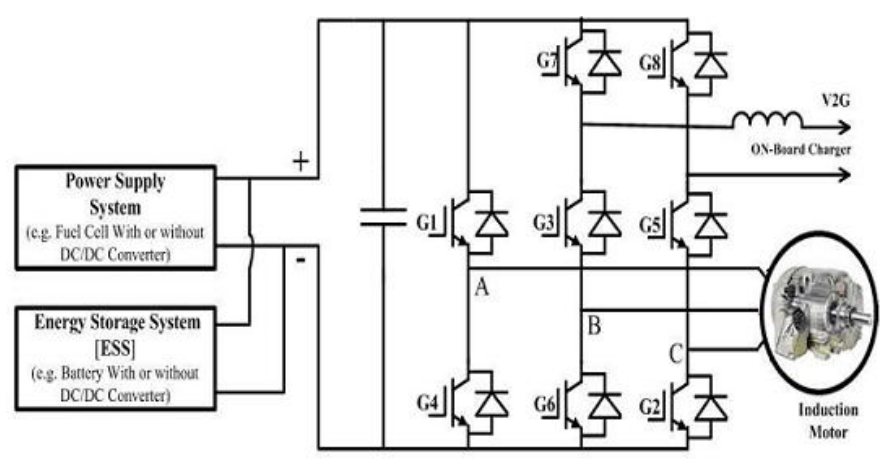

Fig. 2. The structure of the proposed ESI.

\section{B. The Interleaved DC/DC Converter}

Interleaving techniques are widely used to reduce input/output ripples and to increase the power capacity of boost converters operating in critical conduction mode [10], [11]. In this research, a bidirectional dual-phase interleaved converter is proposed for the battery discharging/ charging in order to reduce the current ripple/voltage ripple, to minimize the size and weight the inductor and to improve reliability of the power electronic system. Furthermore, the proposed $\mathrm{DC} / \mathrm{DC}$ converter is used for battery system to reduce its size and weight. Fig. 3 illustrates the proposed DC/DC converter. Development of small-signal transfer functions for non-linear pulse-width modulated (PWM) DC-DC Converters can aid in ease of understanding circuit performance and control [11], [12]. To obtain a certain performance objective, an accurate model is essential. The state space averaged modeling is widely used for modeling the PWM DC-DC converters.

In this paper, the small-signal transfer functions from duty cycle to inductor current and from duty cycle to output voltage in continuous current mode (CCM) for the boost converter are derived as follows:

$$
\begin{gathered}
G_{v d}(s)=\frac{\hat{v}_{o}(s)}{\hat{d}(s)}=G_{d v} \frac{\left(1+\frac{s}{\omega_{z v 1}}\right)\left(1-\frac{s}{\omega_{z v 2}}\right)}{\Delta(s)} \\
G_{i d}(s)=\frac{\hat{i}_{L}(s)}{\hat{d}(s)}=G_{d i} \frac{\left(1+\frac{s}{\omega_{z i}}\right)}{\Delta(s)}
\end{gathered}
$$

Where:

$$
\begin{gathered}
G_{d v}=\frac{V_{o}}{(1-D)}\left[\frac{n(1-D)^{2} R_{O}-R_{L}}{n(1-D)^{2} R_{O}+R_{L}}\right] \cong \frac{V_{o}}{(1-D)} \\
\omega_{z v 1}=\frac{1}{C R_{C}}
\end{gathered}
$$




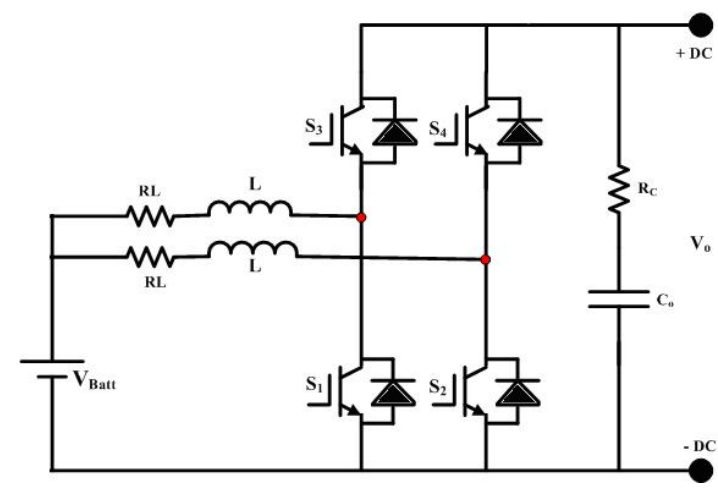

Fig. 3. The Proposed Dual-Phase Interleaved DC/DC converter.

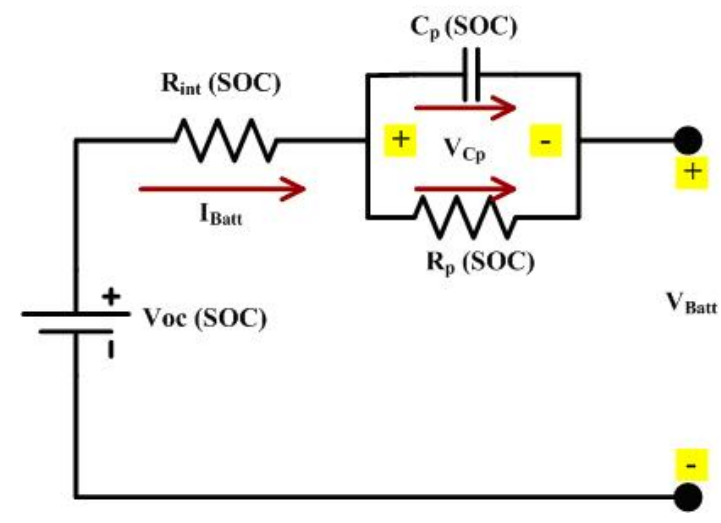

Fig. 4. Thevenin battery Model.

$$
\begin{gathered}
\omega_{z v 2}=\frac{n(1-D)^{2} R_{O}-R_{L}}{L} \\
\Delta(s)=\frac{s^{2}}{\omega_{0}^{2}}+\frac{s}{Q \omega_{0}}+1 \\
\omega_{0}=\sqrt{\frac{n(1-D)^{2} R_{o}+R_{L}}{L C\left(R_{o}+R_{C}\right)}}, Q=\frac{1}{2 \xi} \\
\xi=\frac{L+C\left[R_{L}\left(R_{o}+R_{C}\right)+n(1-D)^{2} R_{o} R_{C}\right]}{2 \sqrt{L C\left(R_{o}+R_{C}\right)\left[n(1-D)^{2} R_{o}+R_{L}\right]}} \\
G_{d i}=\frac{2 V_{o}}{n(1-D)^{2} R_{o}+R_{L}} \\
V_{o}=\frac{1}{(1-D)}, \quad I_{L}=\frac{V_{b}}{n(1-D) R_{o}}, \text { and } R_{o}=\frac{V_{o}^{2}}{P_{o}}
\end{gathered}
$$

Where $V_{o}$ is output voltage, $C$ is the capacitance, $L$ is the inductance, $R_{L}$ is the internal resistance of the inductor, $R_{C}$ is the internal resistance of the capacitor, $n$ is the number of phases $(n=2), V_{\text {Batt }}$ is battery voltage, $D$ is the duty ratio, $P_{o}$ is the output power and $R_{O}$ is the equivalent resistance for the load. Therefore, the boost converter under feedback control is a nonlinear function of the duty cycle, which leads the controller design of the boost converter much more challenging from the viewpoint of stability and bandwidth compared with the Buck DC/DC converter. The controller of the converter has been explained in section IV.

The mathematical modeling of the Li-Ion battery package used in the simulation program is introduced as Thevenin

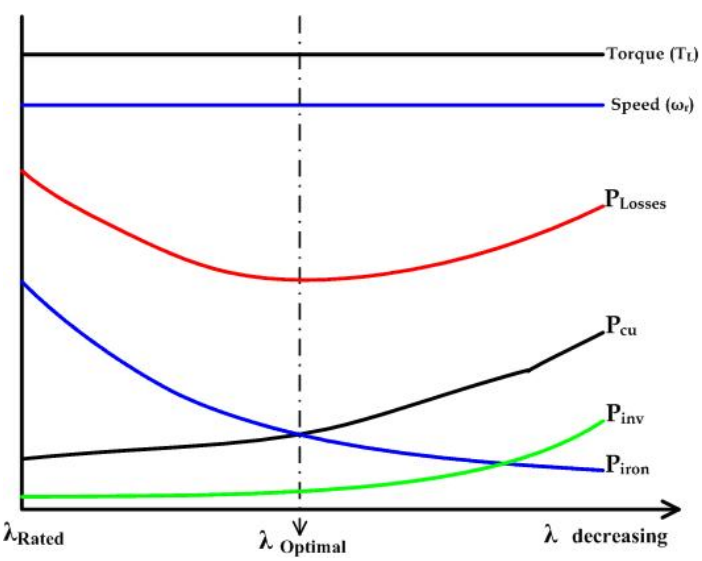

Fig. 5. Losses variation of the motor with varying flux.

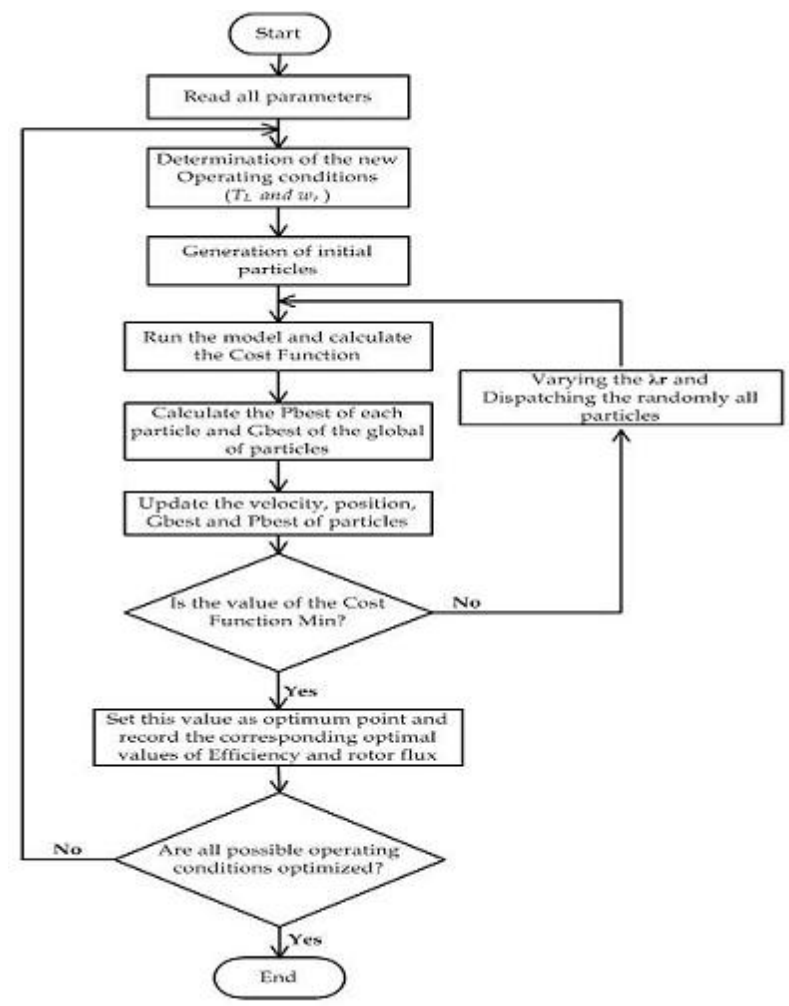

Fig. 6. Flowchart of optimization process by PSO.

Battery Model [13]. All elements in the model are functions of the battery state of charge (SOC). Fig. 4 illustrates the Thevenin battery model. The parameters of the battery are determined by using look-up tables based on experimental data presented in Appendix A.

\section{The Control Strategies}

In this section, there are four control strategies are investigated to validate the regulation performance of the proposed converters. These are indirect field-oriented controller (IFOC) indirect field-oriented controller (IFOC) based on PSO, dual-loop controller for DC/DC interleaved converter and Proportional-Resonant controller (PRC) for battery charger $(\mathrm{G} 2 \mathrm{~V})$ and Vehicle to Grid (V2G) or V2H. 


\section{A. Indirect Field-Oriented Control (IFOC)}

In recent years, the development of field-oriented control has opened the possibility of using AC motors for precision control. The indirect field-oriented control scheme is the most popular scheme for field-oriented controllers. It provides material decoupling between the torque and flux currents Furthermore, the indirect field oriented control (IFOC) consists of controlling the stator current is represented by a vector control.

IFOC allows the stator current to be decoupled into torque producing and flux producing components that can be controlled and maintained- independent of each other, making the control much similar to that of a separately excited DC motor [14]-[16]. The required d-axis component of the stator current, $i_{d s}$, to achieve a given rotor flux magnitude demand $\lambda r^{*}$, can be determined from eq. (12).

$$
\lambda_{r}^{e}=L_{m} * i_{d s}^{e}
$$

The required q-axis component of the stator current, $i_{q s}$, for a given torque demand $\left(T e^{*}\right)$, can be determined from eq. (13).

$$
T_{e}=\frac{3}{2} \frac{P L_{m}}{2 L_{r}}\left[\begin{array}{ll}
i_{q s}^{e} & \lambda_{r}^{e}
\end{array}\right]
$$

For the d-axis of the synchronously rotating reference frame to be aligned with the rotor flux, the 'slip relation', eq. (14), must be maintained.

$$
\omega_{s l}=\omega_{e}-\omega_{r}=\frac{L_{m}}{\tau_{r} * \lambda_{r}^{e}} i_{q s}^{e} .
$$

The torque demand $\left(T e^{*}\right)$ is calculated from speed controller (PI controller) as follows [16]:

$$
\begin{gathered}
T_{e}^{*}=K_{p} \Delta \omega+K_{i} \int \Delta \omega d t \\
K_{p}=2 J * \xi * \omega_{n}-B \\
K_{i}=J * \omega_{n}^{2} .
\end{gathered}
$$

It is clear that, the IFOC with a constant rated rotor flux generally exhibits poor efficiency of the motor at low load. If significant energy savings need to be obtained, it is necessary to optimize the efficiency of the motor. The optimum efficiency of the motor is obtained by the evaluation of the optimal rotor flux level [14]. To implement the efficiency optimization of the induction motor, the loss model is essential.

\section{B. IFO Based PSO}

Minimization of the loss in the induction motor is directly related to the selection of the flux level at any operating point. In this article, particle swarm optimization (PSO) is applied to evaluate the optimal flux. It has the straightforward goal of minimizing the total losses for a given load and speed.
1) Loss Model for Induction Motor: In the development of the loss model, a simplified induction motor model with iron losses is developed. For this purpose, it is necessary to transform all machine variables to the synchronous reference frame [14], [15]. Stator copper, rotor copper and iron losses dominate the overall power loss compared to stray, friction, and converter losses. In the current work, the stray loss is neglected. The total electrical losses can be expressed as follows:

$$
P_{\text {Losses }}=P_{c u 1}+P_{c u 2}+P_{\text {iron }}+P_{i n v}
$$

The total losses of the motor $\left(T P_{\text {losses }}\right)$ are given as follows:

$$
T P_{\text {Losses }}=P_{\text {Losses }}+P_{\text {fric }}
$$

Where $P_{c u 1}$ is the stator copper losses, $P_{c u 2}$ is the rotor copper losses, $P_{\text {iron }}$ is the iron losses, $P_{i n v}$ is the estimated inverter losses and $P_{\text {fric }}$ is the friction loss. The total electrical losses $\left(P_{\text {losses }}\right)$ can be rewritten as:

$$
\begin{gathered}
P_{\text {losses }}=\frac{3}{2}\left[\begin{array}{c}
R_{s}\left(i_{q s}^{e^{2}}+i_{d s}^{e^{2}}\right)+R_{r}\left(i_{q r}^{e^{2}}+i_{d r}^{e^{2}}\right) \\
+\left(\frac{v_{q m}^{2}}{R_{q f e}}+\frac{v_{d m}^{e^{2}}}{R_{d f e}}\right) \\
+\left[k_{1 \text { inv }}\left(i_{q s}^{e^{2}}+i_{d s}^{e^{2}}\right)+k_{2 i n v} \sqrt{\left(i_{q s}^{e^{2}}+i_{d s}^{e^{2}}\right)}\right]
\end{array}\right] \\
v_{d m}^{e}=-\frac{\omega_{e} L_{l r} L_{m}}{L_{r}} i_{q s}^{e}, \text { and } v_{q m}^{e}=\omega_{e} L_{m} i_{d s}^{e} \\
i_{q r}^{e}=-\frac{L_{m}}{L_{r}} i_{q s}^{e}, \text { and } i_{d r}^{e}=0 .
\end{gathered}
$$

The total electrical losses are obtained as follows:

$$
\begin{gathered}
P_{\text {losses }}=\frac{3}{2}\left[\begin{array}{c}
R_{s}\left(i_{q s}^{e^{2}}+i_{d s}^{e^{2}}\right)+R_{r}\left(\frac{L_{m}}{L_{r}} i_{q s}^{e}\right)^{2} \\
+\frac{1}{R_{q f e}}\left[\left(\frac{\omega_{e} L_{l r} L_{m}}{L_{r}} i_{q s}^{e}\right)^{2}+\left(\omega_{e} L_{m} i_{d s}^{e}\right)^{2}\right] \\
+\left[k_{1 \text { inv }}\left(i_{q s}^{e^{2}}+i_{d s}^{e^{2}}\right)+k_{2 i n v} \sqrt{\left(i_{q s}^{e^{2}}+i_{d s}^{e^{2}}\right)}\right]
\end{array}\right] \\
\text { Efficiency }(\eta)=\frac{P_{\text {out }}}{P_{\text {out }}+\mathrm{TP}_{\text {losses }}} .
\end{gathered}
$$

The equation (23) is the cost function, the electrical losses formula, which depends on rotor flux $(\lambda r)$ according to the operating point as described in equations (12-23). Fig. 5 presents the typical distribution of losses in a convertermachine system and its variation with the flux for a certain steady state (low-load torque and a certain speed).

As the flux reduces from the rated value, the core losses decrease, but the motor copper losses increase. However, the total losses decrease to a minimum value and then increase again. It is desirable to set the rotor flux at the optimal value, so that the efficiency is optimum.

2) Particle Swarm Optimization [PSO]: As swarm intelligence is based on real-life observations of social animals (usually insects), it is more flexibility and robust than any traditional optimization methods. PSO method is a member of the wide category of SI methods [14]. The PSO can be represented by the concept of velocity and position. The Velocity (v) and the current position (S) of each agent can be modified by the following equations [14], [17]:

$$
v^{k+1}=w v_{i}^{k}+c_{1} r_{1} *\left(\text { pbest }_{1}-s_{i}^{k}\right)+c_{2} r_{2} *\left(\text { gbest }-s_{i}^{k}\right)
$$




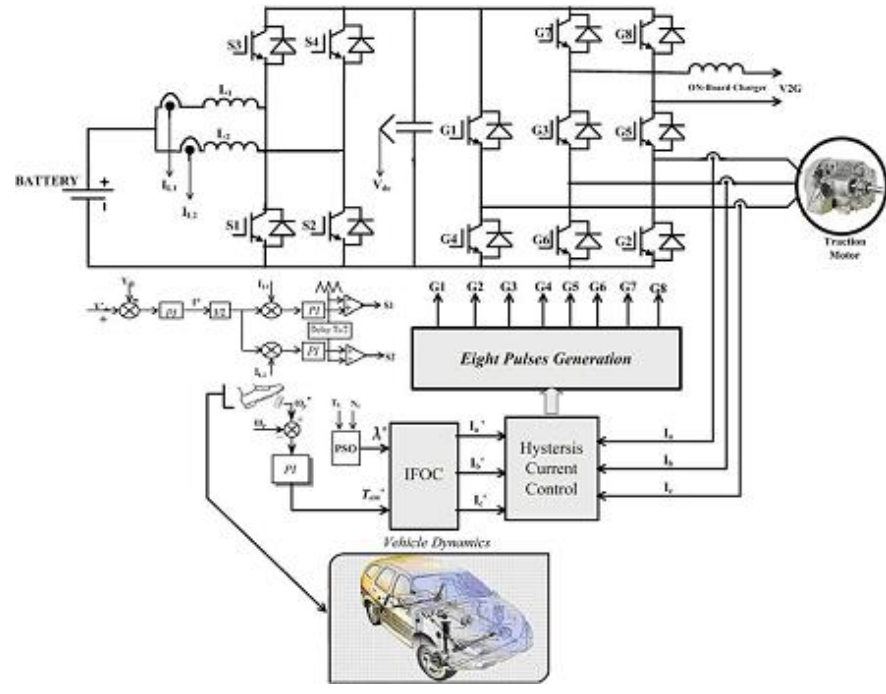

Fig. 7. the proposed system with IFOC based PSO.

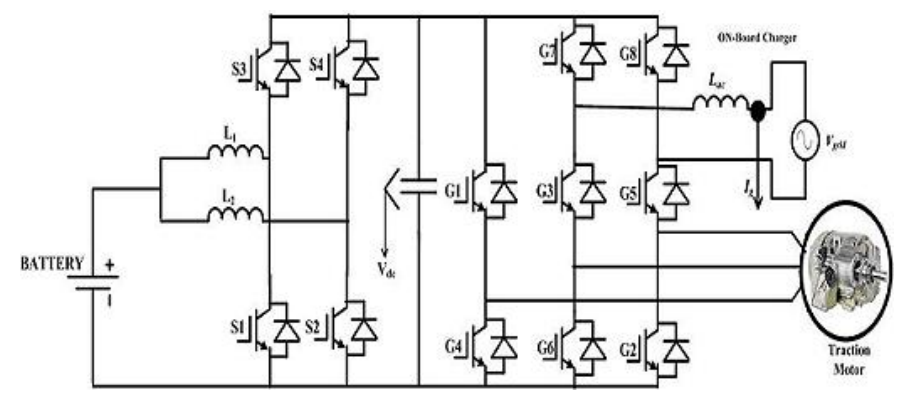

(a)

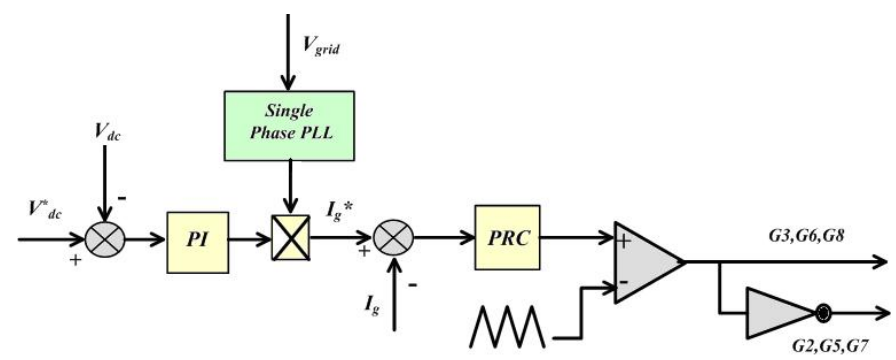

(b)

Fig. 8. The Charging Mode. (a) The proposed system for G2V, and, (b) the proposed controller based PRC.

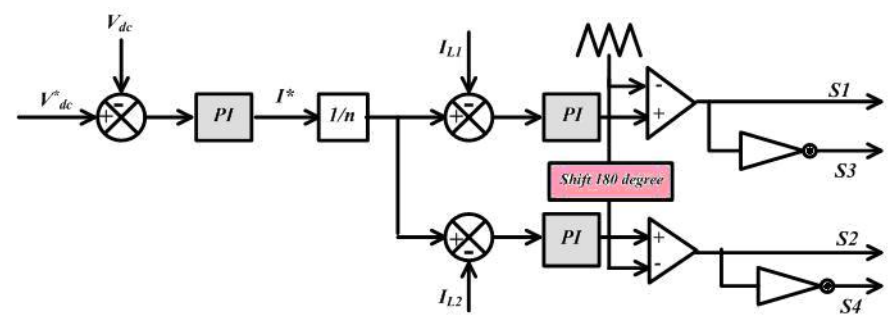

Fig. 9. Dual-loop control strategy structure for Bidirectional converter.

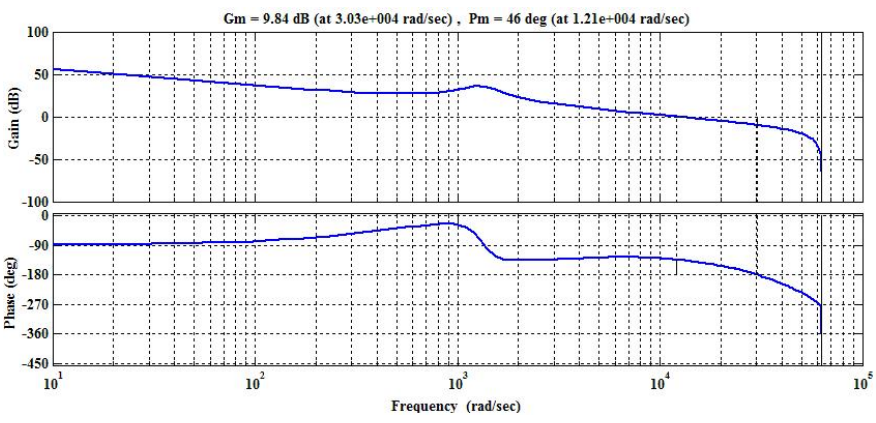

Fig. 10. Current loop gain.

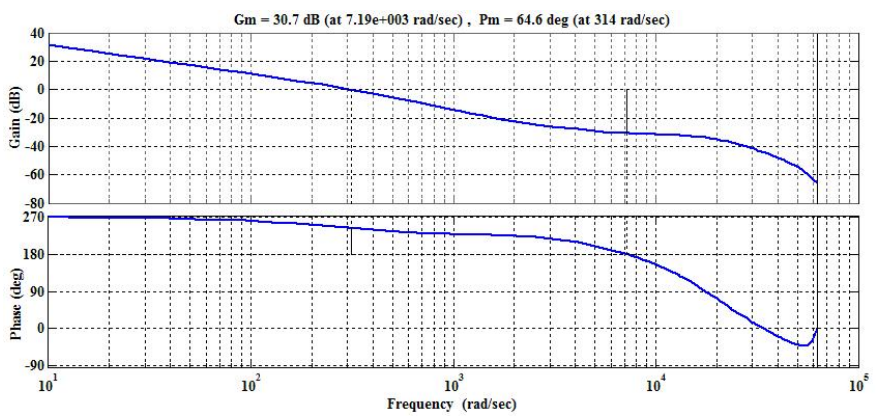

Fig. 11. Voltage loop gain.

$$
S_{i}^{k+1}=S_{i}^{k}+v_{i}^{k+1}
$$

Where $w$ is weight, $r_{1}$ and $r_{2}$ are random numbers [0 1], pbest is the previous best position, gbest) is called the global best of the swarm, $c_{1}$ and $c_{2}$ are positive constants $[c 1+c 2<4)$, and $S$ is the position.

In this paper, PSO is applied to evaluate the optimal flux that minimizes the total losses (Cost Function). Fig. 6 illustrates the flowchart of the execution of PSO during optimization process. The problem can be formulated as follows:

$$
\text { Minimize } T P_{\text {losses }}\left(\lambda r, T_{e}, \omega_{r}\right)
$$

Fig. 7 presents the proposed system and its control strategy. The parameters used of the PSO are shown in Appendix A.

\section{Proportional- Resonant Controller (PRC)}

The Power Factor Correction (PFC) is necessary for AC-toDC converter mode in order to comply with the international standards, such as IEC-dateDay2Month3Year10001strans10003-2 and IEEE-519. In order to control AC current, the Proportional-Resonant Controller (PRC) has been chosen. PRC is quite similar to well known PI controller, but integral part is generalized integrator in stationary frame [18], [19]. The PRC is more effective in stationary frame than a PI controller at achieving zero steady state error and enhances the reference tracking capability. The transfer function of PRC is defined as:

$$
G(s)=k_{p}+\frac{2 k_{i} s}{s^{2}+\omega_{0}^{2}}
$$

Here $K_{p}$ determines the dynamic response of the system, $K_{i}$ adjusts the phase shift between the output and the reference, and $\omega_{0}$ is the resonant frequency which is set to $314.16 \mathrm{rad} / \mathrm{s}$ in this case. Fig. 8 shows the proposed converter during battery charger mode. This control strategy is compared with the hysteresis current control. 


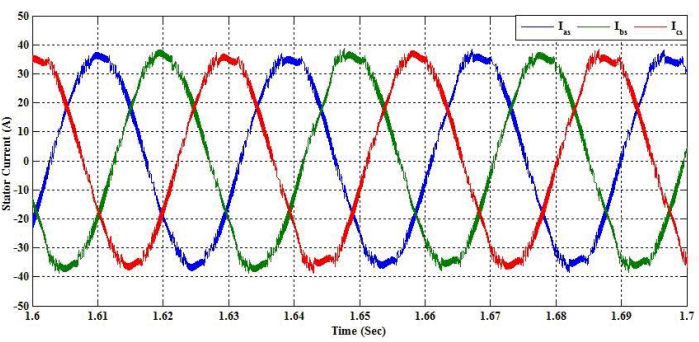

(a)

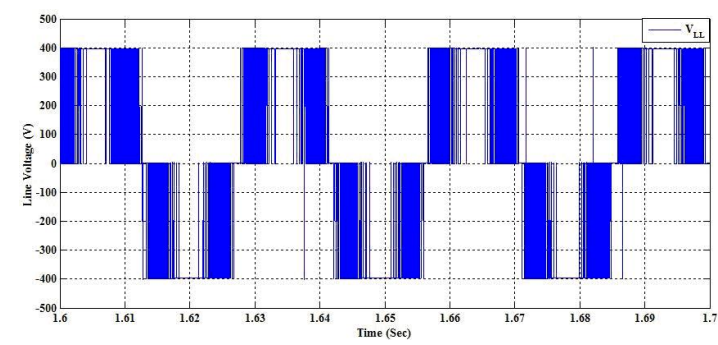

(b)

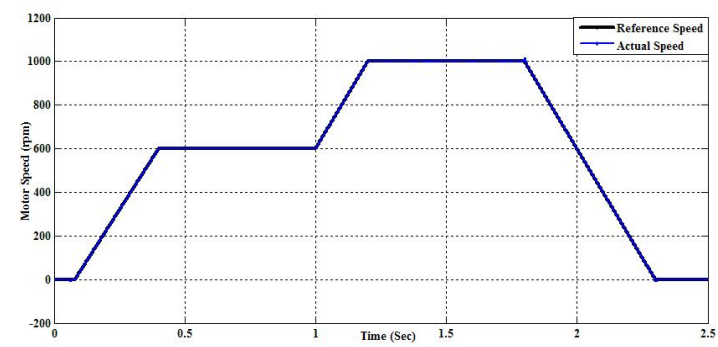

(c)

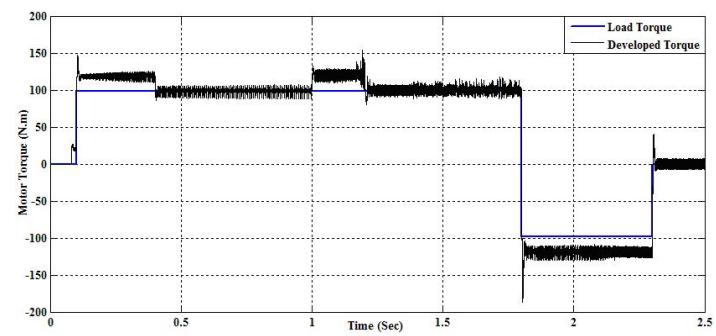

(d)

Fig. 12. Simulation results of the motor. (a) The stator current. (b) the Lineto-Line voltage of the stator. (c) The reference and actual speeds and, (d) The torque-time curve (the dynamic torque $=\mathrm{Te}-\mathrm{T}_{\mathrm{L}}$ depends on the moment inertia of the motor).

\section{Dual-Loop Controller for DC/DC Converter}

In this paper, simple feedback PI controllers are used to maintain a constant bus voltage of $400 \mathrm{~V}$ in the DC/DC converter output, irrespective of the variations in load and input voltage. The PI controllers will be designed based on the required phase margin $(\Phi m)$ and critical frequency $\left(\omega_{w c}\right)$ using bode-diagram, as explained in [20]. The transfer function of the PI controller in $\omega$-domain is given by:

$$
G_{c}(w)=k_{p}+\frac{k_{i}}{s}
$$

Where:

$$
k_{p}=\frac{\cos \theta}{\left|G_{p}\left(j \omega_{w c}\right)\right|}
$$

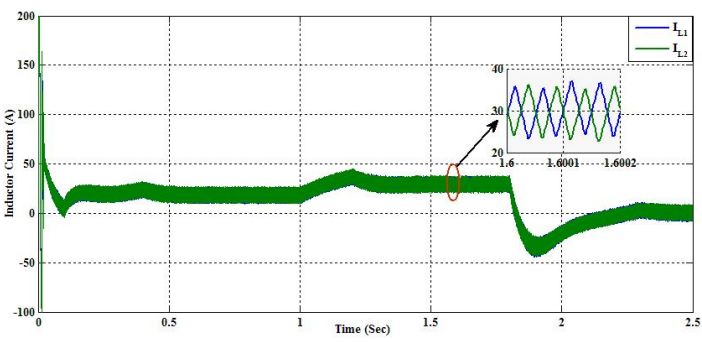

(a)

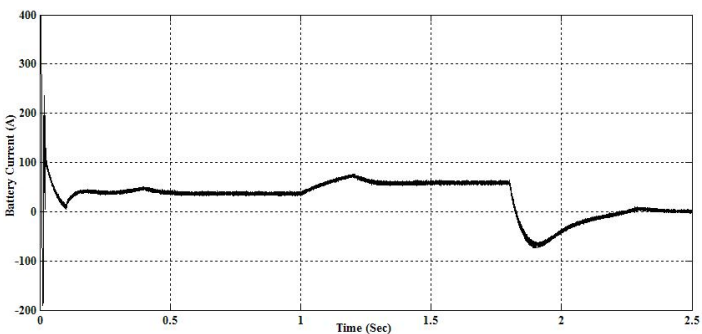

(b)

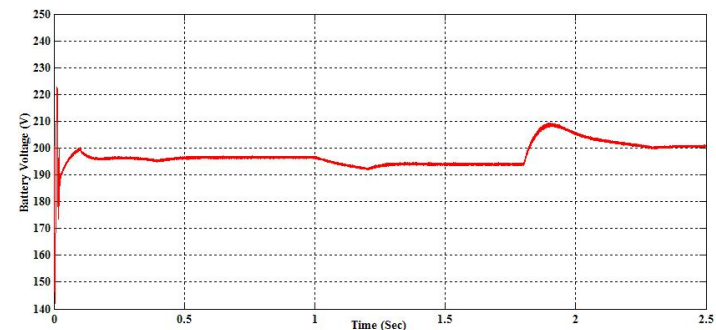

(c)

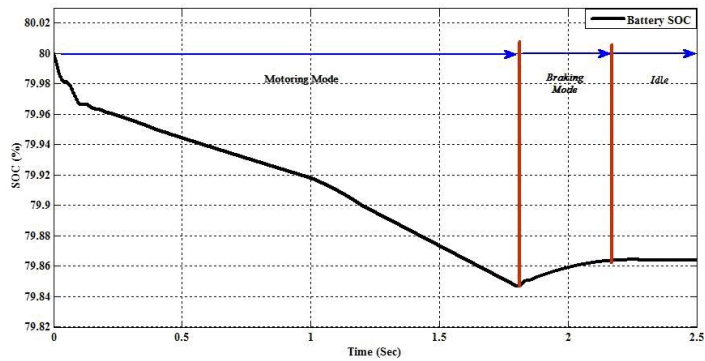

(d)

Fig. 13. The battery performance with DC/DC converter. (a) The inductor currents of the converter. (b) The battery current. (c) The battery voltage and, (d) The battery state of charge (SOC).

$$
\begin{gathered}
k_{i}=\frac{-\omega_{w c} \sin \theta}{\left|G_{p}\left(j \omega_{w c}\right)\right|} \\
\theta=180+\phi_{m}-\angle G_{p}\left(j \omega_{w c}\right) .
\end{gathered}
$$

The $G_{p}$ is the transfer function of the open loop system (e.g. $G_{v d(s)}$, or $G_{i d(s)}$ as is mentioned in section III. Fig. 9 illustrates the block diagram of the control strategy. Fig. 10 and Fig. 11 illustrate the Bode plots for the current loop gain and voltage loop gain of the controller, respectively.

The plots demonstrate that the current loop gain has a crossover frequency of $2 \mathrm{kHz}$, with a phase margin of $46^{\circ}$. To avoid interaction between the sub-systems and to accommodate the battery dynamic response, low control bandwidth is used for voltage loop outer voltage loop has a crossover frequency of $50 \mathrm{~Hz}$ and a phase margin of $64.6^{\circ}$. 


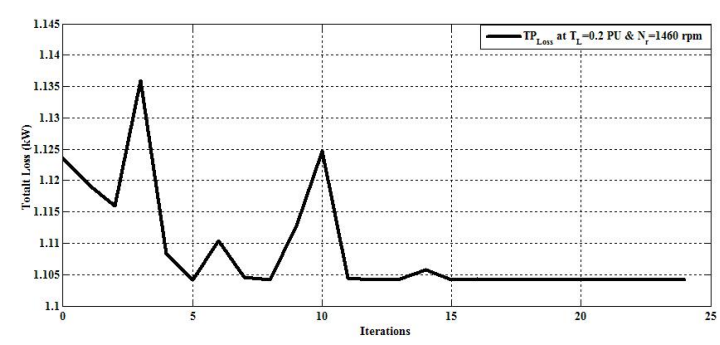

(a)

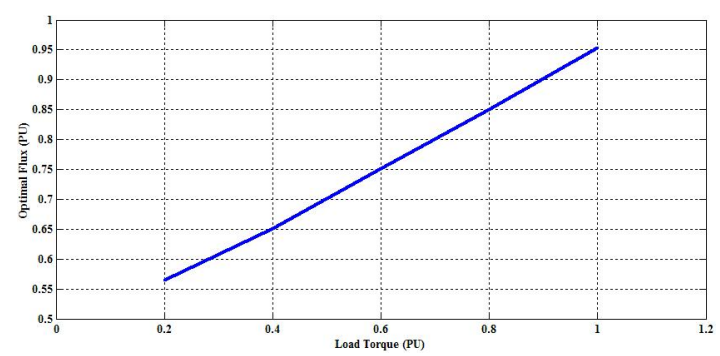

(b)

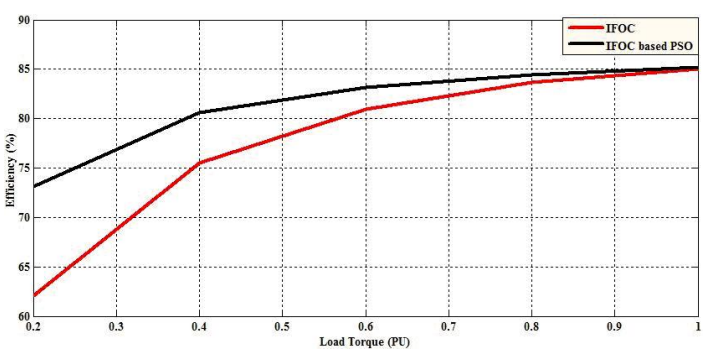

(c)

Fig. 14. the performance of the IFOC based PSO at rated speed. (a) Total losses against iterations (at TL=0.2 PU \& Nr=1460 rpm) during optimization process. (b) The optimal flux against the load torque. (c) The comparison of the efficiency between IFOC and IFOC based PSO.

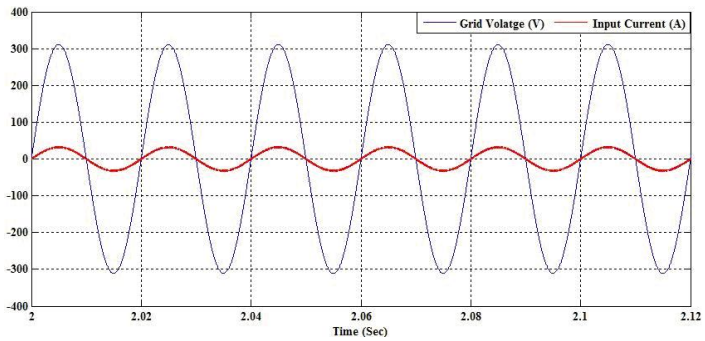

(a)

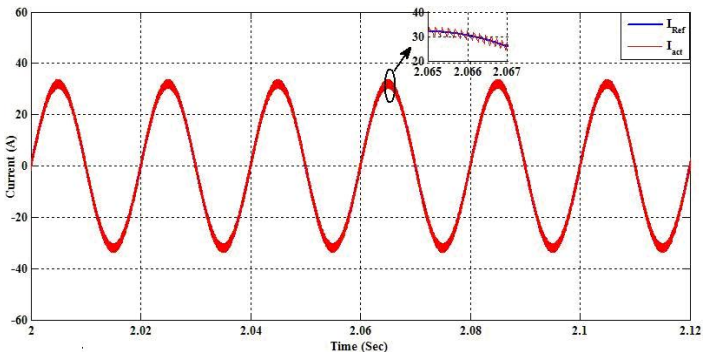

(b)

Fig. 15. Charging mode with HCC controller. (a) Unity power factor of the grid side voltage and the input current. (b) The reference input current and the actual input current.

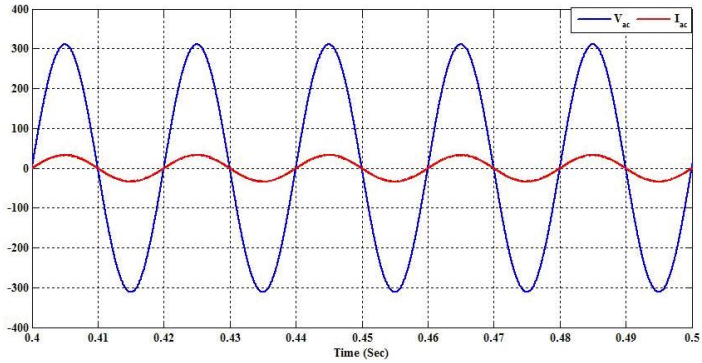

(a)

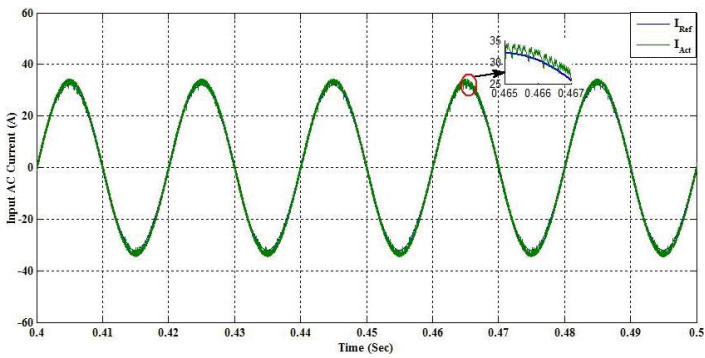

(b)

Fig. 16. Charging mode with PI controller. (a) Unity power factor of the grid side voltage and the input current. (b) The reference input current and the actual input current.

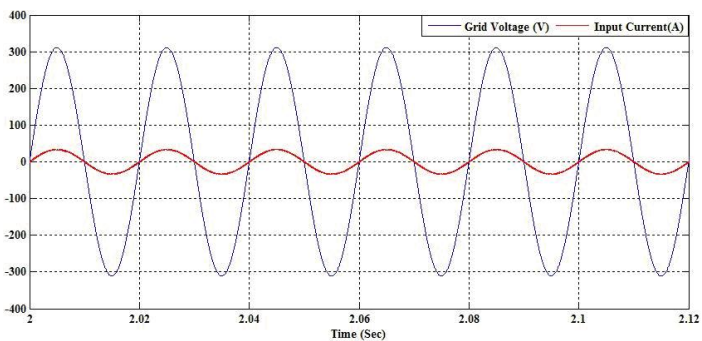

(a)

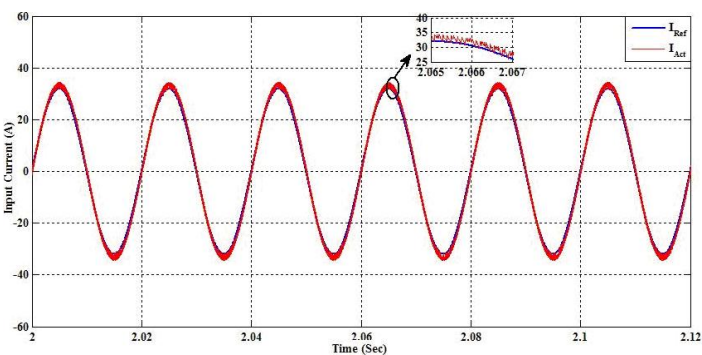

(b)

Fig. 17. Charging mode with PRC controller. (a) Unity power factor of the grid side voltage and the input current. (b) The reference input current and the actual input current.

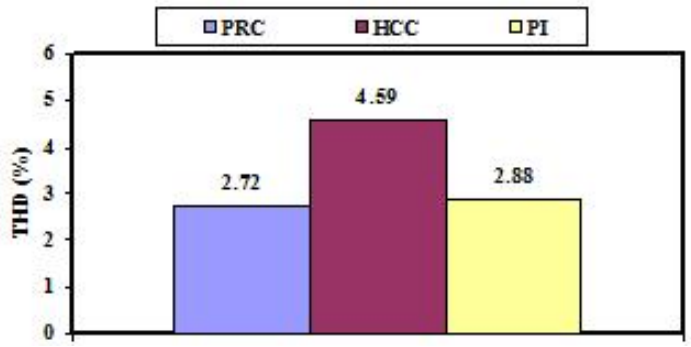

Fig. 18. The input current THD during G2V or V2G. 


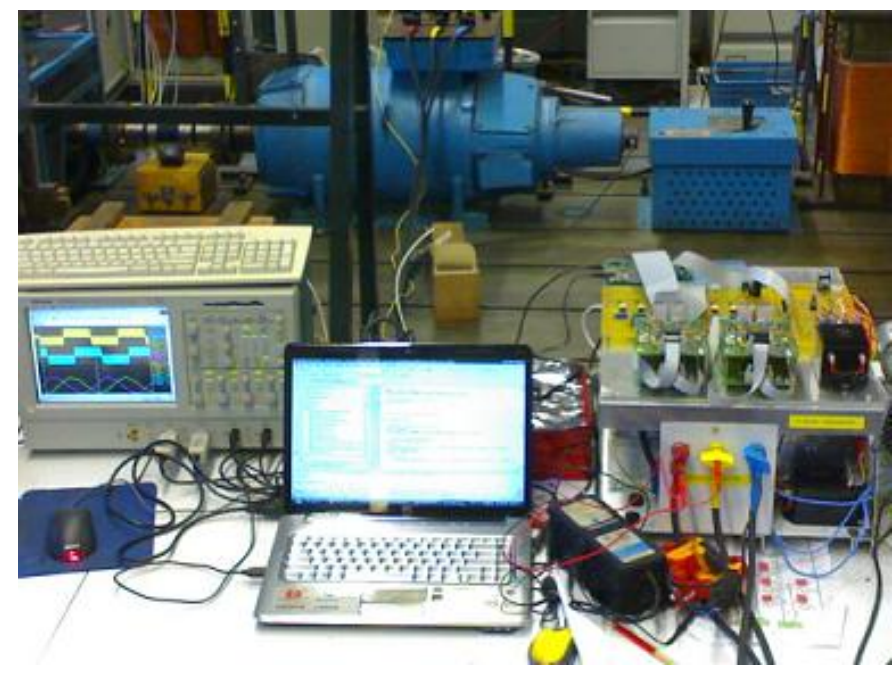

Fig. 19. the experimental Setup of the proposed system.

\section{Simulation Results}

To evaluate the performance of the proposed converter, simulations have been performed by the use of MATLAB/ SIMULINK software based on the before mentioned system equations. These simulations are carried out on three-phase induction motor, and the motor parameters are mentioned in the Appendix A. The battery package parameter is shown in Appendix A. Fig. 12 shows the performance of the proposed system when the PSO is applied side-by-side IFOC. The dynamic response of the battery and the bidirectional DC/DC converter during operation are shown in Fig. 13. Fig. 14 illustrates the optimal efficiency and rotor flux during optimization process for the $\mathrm{AC}$ drive system (motor and ESI). Fig. 15, Fig. 16 and Fig. 17 show the performance of the proposed converter when the Hysteresis current controller (HCC), Proportional- Integral Controller (PI) and PRC are applied at battery charging from grid, respectively.

Fig. 18 shows the comparative study of the input current THD between the control strategies of V2G or G2V.

\section{EXPERIMENTAL RESULTS}

In order to verify the obtained simulation results, the prototypes of $30 \mathrm{~kW}$ bidirectional eight-switch inverter (ESI) and DC/DC interleaved converter are designed, built and integrated in the laboratory in order to drive a $19 \mathrm{~kW}$ induction motor. The F2808 DSP is used for control strategies implementation, SKHI 23/12 gate driver for IGBT. The shaft encoder, LEM current and voltage sensors are used for measuring feedback signals. The required measuring and interface circuits are designed and built. Fig. 19 shows the experimental setup of the proposed system. The motor is loaded by using Eddy current braking. Fig. 20 presents the preliminary experimental results of the motor and its performances. Fig. 21 illustrates the measured efficiency of the ESI.

Fig. 22 and Fig. 23 show the response of the DC/DC interleaved converter under load step with the proposed control strategy and input voltage step, respectively. Fig. 24 presents the steady state inductor currents of the DC/DC interleaved converter.

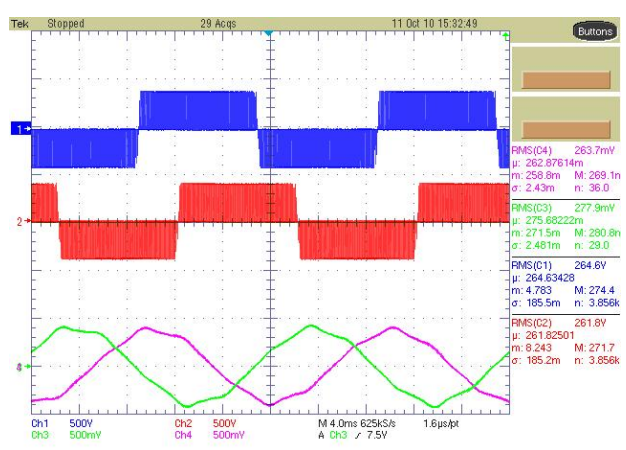

(a)

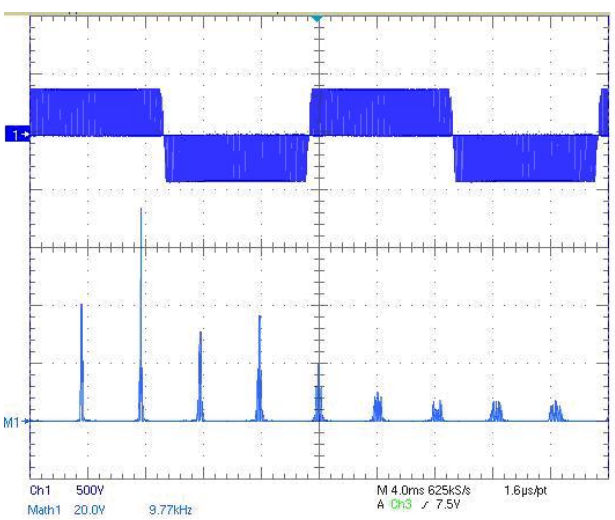

(b)

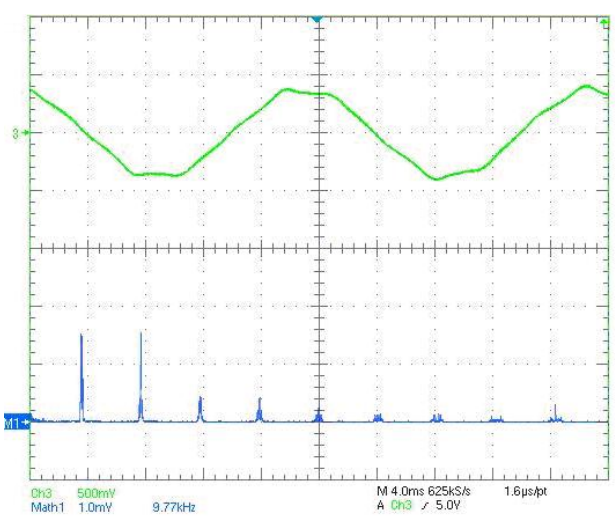

(c)

Fig. 20. the experimental results of the motor. (a) the steady state line-line voltage (500 V/div.) and current (10mV/A). (b) The line voltage harmonics, and c) the stator current harmonics.

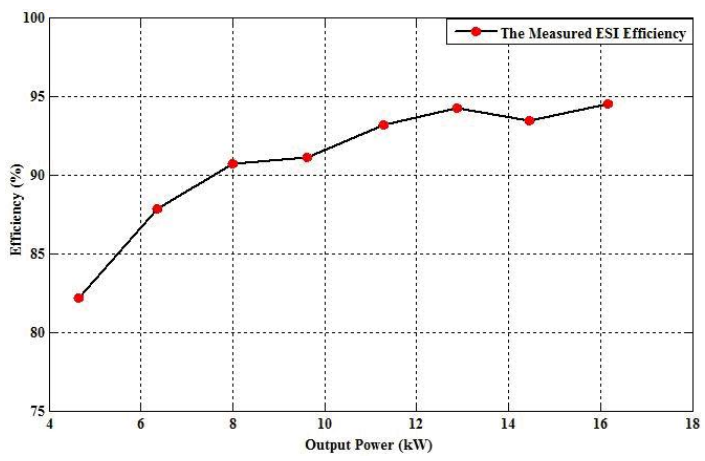

Fig. 21. The Efficiency of the ESI against output power during Mode 1. 


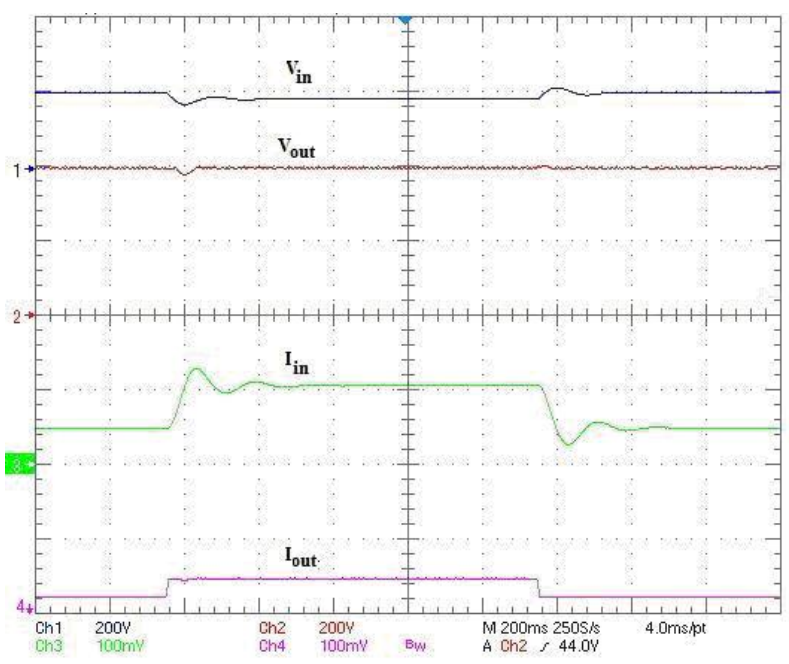

Fig. 22. The response of the DC/DC interleaved converter $(1 \mathrm{mV} / \mathrm{A}$, and 200 V/div) under load step.

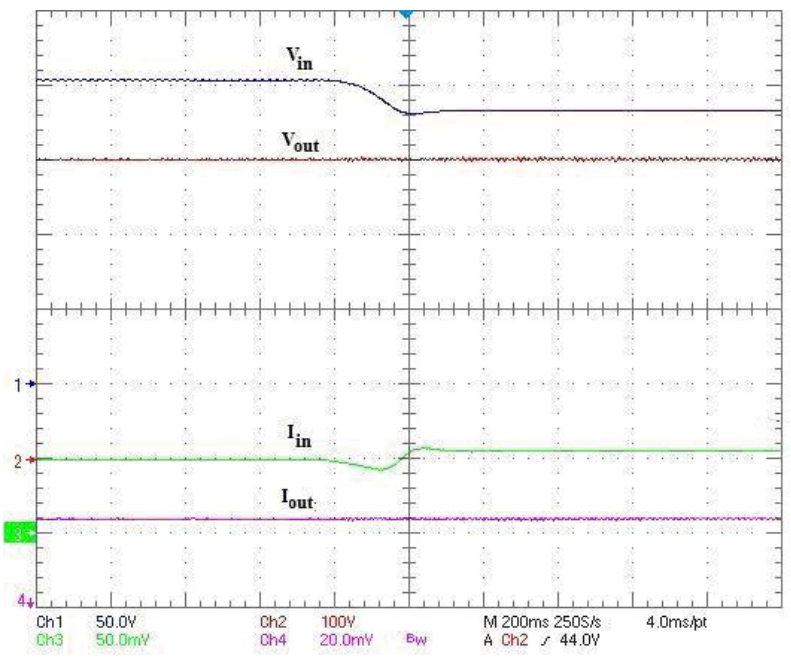

Fig. 23. The response of the DC/DC interleaved converter $(1 \mathrm{mV} / \mathrm{A}$, and $200 \mathrm{~V} / \mathrm{div}$ ) under input voltage step or variation.

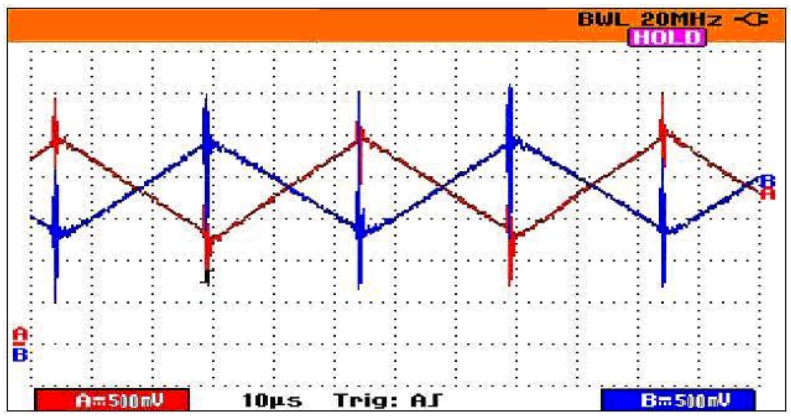

Fig. 24. the inductor currents of the interleaved converter (40mV/A).
The experimental implementation to evaluate the proposed converter in battery charger/V2G will be performed in the near future as well.

\section{CONCLUSION}

In this paper, a novel bidirectional DC/AC, Eight-Switch Inverter (ESI), and interleaved DC/DC converter are proposed to achieve an integrated power electronics interface for PHEV applications. The proposed ESI has been analyzed and its performance characteristics have been presented. The functionalities for the four operating modes (i.e., DC/AC inverter for motoring mode, AC/DC converter for braking mode, single-phase AC/DC PWM rectifier for battery charger, and single-phase $\mathrm{DC} / \mathrm{AC}$ inverter for $\mathrm{V} 2 \mathrm{G}$ ) have been verified. Moreover, the bidirectional interleaved DC/DC converter and its controller are proposed to reduce the input/output ripples with high efficiency and to maintain the DC-Link voltage. A dual-loop control method is employed to achieve the fast transient response.

In addition, the motor can operate with high performance after using IFOC based PSO at any operating point especially at low load. The Proportional-Resonant Controller is more efficient than other control strategies to reduce the input current THD to be $2.72 \%$ for battery charger mode as well as V2G. Finally, the results have demonstrated that the proposed topology has achieved all the operating modes successfully and it promises significant savings in component count with high performance for PHEVs compared with other topologies. Therefore, it can be expected that this study can be utilized for development of high efficiency PHEV system.

\section{APPENDIX A}

TABLE I

THE MOTOR PARAMETERS

\begin{tabular}{|c|c|c|c|}
\hline Rated power & $20 \mathrm{HP}$ & $\begin{array}{c}\text { Stator leakage } \\
\text { inductance }\left(L_{l s}\right)\end{array}$ & $991 \mu \mathrm{H}$ \\
\hline $\begin{array}{c}\text { Rated line } \\
\text { voltage }\end{array}$ & $400 \mathrm{~V}$ & $\begin{array}{c}\text { Rotor leakage } \\
\text { inductance }\left(L_{l r}\right)\end{array}$ & $991 \mu \mathrm{H}$ \\
\hline $\begin{array}{c}\text { Rated frequency } \\
\text { Rated Speed } \\
\left(N_{r}\right)\end{array}$ & $1460 \mathrm{rpm}$ \\
\hline $\begin{array}{c}\text { Stator resistance } \\
\left(R_{S}\right)\end{array}$ & $0.2147 \Omega$ & $\begin{array}{c}\text { Moment of } \\
\text { Inertia }(\mathrm{J})\end{array}$ & $0.102 \mathrm{~kg} . \mathrm{m}^{2}$ \\
\hline $\begin{array}{c}\text { Rotor resistance } \\
\left(R_{r}\right)\end{array}$ & $0.2205 \Omega$ & $\begin{array}{c}\text { Friction } \\
\text { Coefficient }(\mathrm{B})\end{array}$ & $\begin{array}{c}0.0095 \\
\text { N.m.sec/r }\end{array}$ \\
\hline $\begin{array}{c}\text { Mutual } \\
\text { inductance }\left(L_{m}\right)\end{array}$ & $0.0642 \mathrm{H}$ & Pole Pairs (P) & 2 \\
\hline$K_{\text {inv1 }}$ & 0.413 & $K_{\text {inv2 }}$ & 0.0250 \\
\hline $\mathrm{Ke}$ & $58 e-5$ & $\mathrm{Kh}$ & $58 e-5$ \\
\hline$R_{f e}$ & $790 \Omega$ & $\xi$ & 0.707 \\
\hline \multicolumn{2}{r|}{} & & \\
\hline
\end{tabular}

TABLE II

THE PARAMETERS OF THE CONVERTERS

\begin{tabular}{|c|c|c|}
\hline \multirow{3}{*}{ DC/DC Converter } & Inductance $\left(L_{1}=L_{2}\right)$ & $375 \mu \mathrm{H}$ \\
\cline { 2 - 3 } & Inductor resistance $\left(R_{L}\right)$ & $34 \mathrm{~m} \Omega$ \\
\cline { 2 - 3 } & Capacitor $(C)$ & $390 \mu \mathrm{F}$ \\
\cline { 2 - 3 } & Capacitor Resistance $\left(R_{C}\right)$ & $1.07 \mathrm{~m} \Omega$ \\
\cline { 2 - 3 } & Switching Frequency $(F s)$ & $20 \mathrm{kHz}$ \\
\hline \multirow{2}{*}{ ESI Converter } & AC Filter Capacitor & $50 \mu \mathrm{F}$ \\
\cline { 2 - 3 } & AC Inductor Filter & $1.3 \mathrm{mH}$ \\
\hline
\end{tabular}


TABLE III

PSO ALGORITHM PARAMETER

\begin{tabular}{|c|c|c|c|}
\hline Population size & 20 & Min. weight $($ wmin $)$ & 0.1 \\
\hline Max. iter & 100 & $\mathrm{r} 1$ & {$[0,1]$} \\
\hline $\mathrm{c} 1$ & 0.5 & $\mathrm{r} 2$ & {$[0,1]$} \\
\hline $\mathrm{c} 2$ & 0.5 & Lower Bound & 0.1 \\
\hline Max. weight $\left(w_{\max }\right)$ & 1.4 & Upper Bound & 2.5 \\
\hline
\end{tabular}

TABLE IV

LI-ION BATTERY PARAMETERS [17]

\begin{tabular}{|c|c|c|c|}
\hline Rated Capacity & $10 \mathrm{Ah}$ & Initial SOC & $80 \%$ \\
\hline Nominal voltage $(\mathrm{V})$ & $3.3 \mathrm{~V}$ & Min. Voltage & $2.9 \mathrm{~V}$ \\
\hline $\begin{array}{c}\text { Max. discharging } \\
\text { Current }\end{array}$ & $250 \mathrm{~A}$ & $\begin{array}{c}\text { Internal } \\
\text { resistance/cell }\end{array}$ & $58 \mathrm{~m} \Omega$ \\
\hline $\begin{array}{c}\text { Number of series cell } \\
\left(N_{s}\right)\end{array}$ & 61 & $\begin{array}{c}\text { Number of } \\
\text { parallel }\left(N_{p}\right)\end{array}$ & 3 \\
\hline
\end{tabular}

\section{REFERENCES}

[1] W. Kramer, S. Chakraborty, B. Kroposki, and H. Thomas, "Advanced power electronic interfaces for distributed energy systems, part 1: systems and topologies", Technical Report, FY2008, 2008.

[2] A. Emadi, Y. J. Lee, and K. Rajashekara, "Power electronics and motor drives in electric, hybrid electric, and plug-in hybrid electric vehicles," IEEE Trans. Ind. Electron., Vol. 55, No. 6, pp. 2237-2245, Jun. 2008.

[3] J. Axsen, A. Burke, and K. Kurani, "Batteries for plug-in hybrid electric vehicles (phevs)," Goals and the State of Technology circa 2008, 2008

[4] L. Shi, A. Meintz, and M. Ferdows, "Single-phase bidirectional ac-dc converters for plug-in hybrid electric vehicle applications," IEEE Vehicle Power and Propulsion Conference (VPPC), 2008.

[5] Y.-J. Lee, A. Khaligh and A. Emadi "Advanced integrated bidirectional ac/dc and $\mathrm{dc} / \mathrm{dc}$ converter for plug-in hybrid electric vehicles," IEEE Trans. Veh. Technol., Vol. 58, No. 8, pp 3970-3980, Oct. 2009.

[6] S. Haghbin, K. Khan, S. Lundmark, M. Alakula, O. Carlson, M. Leksell, and O. Wallmark, "Integrated chargers for EVs and PHEVs: examples and new solutions," IEEE International Conference on Electrical Machines (ICEM) proceedings, 2010.

[7] S. Lacroix, E. Laboure, and M. Hilairet, "An integrated fast battery charger for electric vehicle," IEEE Vehicle Power and Propulsion Conference, 2010.

[8] D. C. Erb, O. C. Onar, A. Khaligh, "Bi-directional charging topologies for plug-in hybrid electric vehicles," in Proc. IEEE Applied Power Electronics Conference and Exposition, pp. 2066-2072, 2010.

[9] G.-Y. Choe, J.-S. Kim, B.-K. Lee, C.-Y. Won, and T.-W. Lee, "A Bidirectional Battery Charger for Electric Vehicles Using Photovoltaic PCS Systems," IEEE Vehicle Power and Propulsion Conference, 2010.

[10] H. Xu, X. Wen, and L. Kong, "Dual-Phase dc-dc converter in fuel cell electric vehicles," 9th IEEE International Power Electronics Congress, 2004.

[11] M. K., Kazimierczuk, Pulse-Width Modulated Dc-Dc Power Converters, John Wiley \& Sons, Ltd, 2008.

[12] C. Sudhakarababu and Mummadi Veerachary, "DSP Based control of interleaved boost converter," Journal of Power Electronics, Vol. 5, No. 3, Jul. 2005

[13] J. Van Mierlo., P. Van den Bossche, G. Maggetto "Models of energy sources for EV and HEV: fuel cells, batteries, ultracapacitors, flywheels and engine-generators," Journal of Power Sources, Vol. 128, No. 1, pp. 76-89, Mar. 2004

[14] A. M. A. Amin, M. I. Korfally, A. A. Sayed, and O. T. M Hegazy, "Efficiency optimization of two asymmetrical windings induction motor based on swarm intelligence," IEEE Trans. Energy Convers., Vol. 24, No. 1, pp. 12-20, Mar. 2009.

[15] K. Aissa and K. D. Eddine, "Vector control using series iron loss model of induction, motors and power loss minimization," World Academy of Science, Engineering and Technology 52, 2009.
[16] O. Hegazy, and J. Van Mierlo, "A novel eight switches inverter operation modes for plug-in hybrid electric vehicle," Electromotion International journal, Vol. 17, No. 3, pp. 191-208, Jul./Sep. 2010.

[17] O. Hegazy, J. Van Mierlo, B. Verbrugge, and O. Ellabban, "Optimal power sharing and design optimization for fuel cell/battery hybrid electric vehicles based on swarm intelligence," The 25th World Battery, Hybrid and Fuel Cell Electric Vehicle Symposium \& Exhibition, Nov.. 2010.

[18] J. Rąbkowski, "Grid-connected Z-source inverter with resonant controller," in Proc. of Nordic Workshop of Power and Industrial Electronics, 2006.

[19] S. Buso and P. Mattavelli, Digital Control in Power Electronics, Morgan and Claypool Publishers, 2006.

[20] O. Ellabban, O. Hegazy, J. Van Mierlo, and P. Lataire, "Dual loop digital control design and implementation of a dsp based high power boost converter in fuel cell electric vehicle," IEEE OPTIM, 2010.

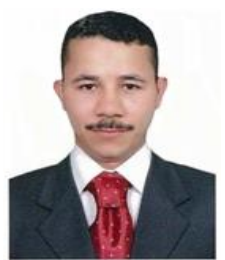

Omar Hegazy (SM'09) was born in Cairo, Egypt, in 1978. He received the B.Sc. and M.Sc. degrees in Electrical Engineering from Helwan University, Cairo, Egypt, where he is currently working toward the Ph.D degree in the Department of Electrical Engineering and Energy Technology (ETEC), Vrije Universiteit Brussel (VUB), Belgium. His current research interests include Power Electronics, Renewable Energy, Control Systems, Electric Drives, Hybrid Electric Vehicles, Plug in Hybrid Electric Vehicles, Power Management Strategies and Optimization Techniques.

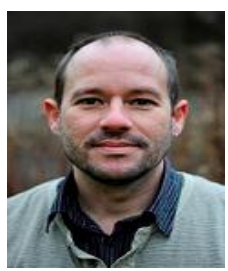

Joeri Van Mierlo obtained his Ph.D. in electromechanical Engineering Sciences from the Vrije Universiteit Brussel in 2000. He is now a full-time professor at this university, where he leads the MOBI - Mobility and automotive technology research centre (http://mobi.vub.ac.be). Currently his activities are devoted to the development of hybrid propulsion (power converters, energy storage, energy management, etc.) systems as well as to the environmental comparison of vehicles with different kind of drive trains and fuels (LCA, WTW). He is the author of more than 200 scientific publications. Prof. Van Mierlo chairs the EPE chapter "Hybrid and electric vehicles" (www.epe-association.org); he is the secretary of the board of the Belgian section of AVERE (ASBE) (www.asbe.be) and is Vice-president of AVERE (www.avere.org). He is editor in chief of the World Electric Vehicle Journal Volume 3 and co-editor of the Journal of Asian Electric Vehicles. He is an active member of EARPA - the European Automotive Research Partner Association. Furthermore he is member of Flanders Drive and of VSWB - Flemish Cooperative on hydrogen and Fuels Cells. Prof. Van Mierlo was Chairman of the International Program Committee of the International Electric, hybrid and fuel cell symposium (EVS24).

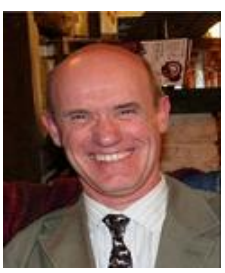

Philippe Lataire received a degree in electromechanical engineering in 1975 and a degree in doctor in applied sciences in 1982 from the Vrije Universiteit Brussel (VUB, Brussels, Belgium). He is presently full professor at the VUB in the field of power electronics, automatic control and electric drives. The prime factors of his research interest are in the field of electric drives, power electronics and control. The Department FirW - ETEC, headed by Prof. Philippe Lataire, developed research activities in the fields of sustainable mobility, computational electrochemistry, lighting, electric machines and power electronics applications. 